\title{
Extraction of Alginate Biopolymer Present in Marine Alga Sargassum filipendula and Bioadsorption of Metallic Ions
}

\author{
Sirlei Jaiana Kleinübing*, Frederico Gaia, Caroline Bertagnolli, Meuris Gurgel Carlos da Silva
}

\author{
School of Chemical Engineering, University of Campinas - UNICAMP, \\ Cidade Universitária Zeferino Vaz, CEP 13081-970, Campinas, SP, Brazil
}

Received: August 1, 2012; Revised: September 19, 2012

\begin{abstract}
This paper studies the bioadsorption of $\mathrm{Pb}^{2+}, \mathrm{Cu}^{2+}, \mathrm{Cd}^{2+}$ and $\mathrm{Zn}^{2+}$ ions by marine alga Sargassum filipendula and by the alginate biopolymer extracted from this alga. The objective is to evaluate the importance of this biopolymer in removing different metallic ions by the marine alga S. filipendula. In the equilibrium study, the same affinity order was observed for both bioadsorbents: $\mathrm{Pb}^{2+}>\mathrm{Cu}^{2+}>\mathrm{Zn}^{2+}>\mathrm{Cd}^{2+}$. For $\mathrm{Pb}^{2+}$ and $\mathrm{Cu}^{2+}$ ions when the alginate is isolated and acting as bioadsorbents, adsorption capacities greater than those found for the alga were observed, indicating that it is the main component responsible for the removal of metallic ions. For $\mathrm{Zn}^{2+}$ and $\mathrm{Cd}^{2+}$ ions, greater bioadsorption capacities were observed for the alga, indicating that other functional groups of the alga, such as sulfates and amino, are also important in the bioadsorption of these ions.
\end{abstract}

Keywords: Sargassum filipendula, extraction, alginate, heavy metals, bioadsorption

\section{Introduction}

Seaweeds are one of the types of macroscopic biomass known for their metal-sorbing potential. In several ocean locations, marine macroalgae are abundant and of very fast growth, which allows them to be easily collected in large quantities ${ }^{1}$.

In brown seaweeds, the capacity of removing several metallic species is attributed to the biochemical constitution of their cellular wall, which is basically composed by three types of biopolymers: alginate, fucoidan and cellulose, which might provide several functional groups as binding sites (amino, carboxyl, sulfates). Alginate is its main polysaccharide, and the presence of mannuronic $(\mathrm{M})$ and guluronic (G) acids in this biopolymer is directly related to the bioadsorption capacity of metallic ions.

Bioadsorption studies with marine alga Sargassum sp. have shown that carboxylic and sulfate groups (present in alginic acid and fucoidan) are active in ionic exchange. The carboxylic groups presented in the biomass are mostly constituted (typically approximately $70 \%$ ) in sites in dry alga and play an important role in bioadsorption, being responsible for approximately $90 \%$ metal immobilization in the process ${ }^{2}$. The alga bioadsorption capacity is directly proportional to the presence of these sites in the alginate polymer.

The alginate biopolymer represents up to $40 \%$ dry matter in brown marine algae. It is a linear polymer with high molecular weight constituted by two uronic acids $-\beta$-Dmannuronic $(\mathrm{M})$ and $\alpha$-L-guluronic $(\mathrm{G})^{3}$. Differences in molecular conformation between $\mathrm{M}$ and $\mathrm{G}$ blocks are the main responsible for the variation in alginate affinity for metallic ions $s^{4,5}$.

Several studies point out the high efficiency of different species of the marine alga Sargassum in the bioadsorption of different metallic ions, many of these using

*e-mail: jaianak@gmail.com
Brazilian Sargassum sp. ${ }^{6-9}$ No studies were found using alginate extracted from Brazilian algae for application as bioadsorbent. The isolated study of this biopolymer as a bioadsorbent might aid the understanding of the mechanisms involved in the bioadsorption process of different metallic ions by the marine alga.

The alginate biopolymer is extracted as sodium alginate and can be characterized by determining the M/G ratio using nuclear magnetic resonance spectroscopy (NRS). The addition of calcium ions to a solution of sodium alginate promotes instantaneous jellification of the contact region, which happens when the calcium ions are diffused through the gel-membrane interface ${ }^{10}$ and the gel formed can no longer be managed.

The mechanism forming alginate gel can be explained by the 'egg box' model for interactions of $\mathrm{G}$ segments with calcium ions. Block $\mathrm{G}$ regions are aligned side by side, resulting in the formation of a cavity, with calcium ions forming the link between the chains, similar to an egg in its package, making a tri-dimensional network.

This study used the jellification process for the preparation of calcium alginate used as the bioadsorbent, where the bioadsorption of $\mathrm{Pb}^{2+}, \mathrm{Cu}^{2+}, \mathrm{Cd}^{2+}$ and $\mathrm{Zn}^{2+}$ ions by marine alga Sargassum filipendula and by the alginate biopolymer extracted from this alga in the form of calcium alginate were evaluated.

\section{Material and Methods}

\subsection{Metal solutions}

In order to perform this study, $\mathrm{Pb}^{2+}, \mathrm{Cd}^{2+}, \mathrm{Cu}^{2+}$ and $\mathrm{Zn}^{2+}$ synthetic solutions were prepared from lead nitrate $\left(\mathrm{Pb}\left(\mathrm{NO}_{3}\right)_{2}\right)$, cadmium nitrate $\left(\mathrm{Cd}\left(\mathrm{NO}_{3}\right)_{2} \cdot 4 \mathrm{H}_{2} \mathrm{O}\right)$, copper nitrate $\left(\mathrm{Cu}\left(\mathrm{NO}_{3}\right)_{2} \cdot 3 \mathrm{H}_{2} \mathrm{O}\right)$ and zinc nitrate $\left(\mathrm{Zn}\left(\mathrm{NO}_{3}\right)_{2} \cdot 6 \mathrm{H}_{2} \mathrm{O}\right)$ 
salts. Concentrations are expressed in $\mathrm{mmol}^{-\mathrm{L}^{-1}}$. The solution $\mathrm{pH}$ was adjusted to 4.5 using nitric acid $\mathrm{HNO}_{3}(0.5 \mathrm{M})$. Heavy metal concentration was determined by Atomic Absorption Spectrophotometer - AA 100 - Perkin Elmer from the Environmental Engineering Laboratory - Unicamp.

\subsection{Marine alga Sargassum filipendula}

The marine alga $S$. filipendula was collected on the North Coast of São Paulo State, in the city of São Sebastião, Brazil. The alga was rinsed with distilled water and dried at $60{ }^{\circ} \mathrm{C}$ for 24 hours prior to being stored. Biomass was grinded and separated by dynamic sieving with a mean diameter of $0.59 \mathrm{~mm}$.

\subsection{Extraction of alginate present in the alga}

The method described by McHugh ${ }^{11}$ was used for extracting the alginate. The dry alga was soaked in formaldehyde $0.4 \%$ for 30 minutes, rinsed with water and dropped into a $\mathrm{HCl}$ solution $\left(0.1 \mathrm{~mol} . \mathrm{L}^{-1}\right)$ for 2 hours. Then, the samples were rinsed again in distilled water before extraction in $2 \%$ sodium carbonate solution. In the presence of excess $\mathrm{Na}_{2} \mathrm{CO}_{3}$, the alginic acid is converted to a sodium alginate, causing polymer dissolution. The alginate extraction was carried out at $60^{\circ} \mathrm{C}$ by soaking for 5 hours. The sample was filtered to separate the alga residue and the precipitated sodium alginate with ethanol.

\subsection{Preparation of alginate for application as bioadsorbent}

In order to be used as adsorbent, calcium alginate beads were prepared. A solution of sodium alginate was prepared by dissolving $5 \mathrm{~g}$ alginate in $100 \mathrm{~mL}$ deionized water under high agitation. The solution was then dripped into an aqueous solution of calcium chloride at $4 \%\left(\mathrm{CaCl}_{2} \cdot 2 \mathrm{H}_{2} \mathrm{O}\right.$, Nuclear brand). The alginate beads were kept in contact with calcium chloride for 24 hours. Following this period, the beads were rinsed in deionized water and left to dry at room temperature.

The morphology of the calcium alginate beads was evaluated by scanning electronic microscopy. This technique allowed to obtain images with high amplification and high resolution, enabling the evaluation of particle forms by means of interaction between an incident ray of electrons scanning the surface of the sample. The samples received carbon coating, and micrographs were obtained in a LEO, model LEO 440i scanning electronic microscope, with increases of 50-, 150- and 3000-fold.

Alginate bead average diameter and sphericity before and after drying were determined by microphotographs obtained in optical microscope coupled to an image acquisition system, using SigmaScan Pro 4 software.

\subsection{Fourier Transform Infrared Spectroscopy (FT-IR)}

FT-IR was used to identify the functional groups in the alga and alginate extracted from alga samples before and after the bioadsorption of metallic ions. Infrared spectra were recorded in the $4000-650 \mathrm{~cm}^{-1}$ region using a Thermo Nicolet instrument, model IR-200. The ATR (attenuated total reflection) device allowed the obtaining of information about the surface.

\subsection{Bioadsorption kinetics}

The behavior of metallic ion bioadsorption kinetics was studied using the marine alga $S$. filipendula and the alginate biopolymer extracted from that alga, with the objective of evaluating the rate of bioadsorption in relation to time. The tests were performed with alginate and alga beads ( $1 \mathrm{~g}$ ) added to $500-\mathrm{mL}$ metallic solution $(\mathrm{pH} 4.5$ and $250 \mathrm{rpm}$ agitation) in a metallic ion initial concentration of approximately $4.0 \mathrm{mmol} . \mathrm{L}^{-1}$.

The metal adsorption capacity by the adsorbents was calculated according to the mass equilibrium, equation 1 .

$q_{j}=\frac{\left(C_{j}^{0}-C_{f}\right) V}{m_{s}}$

where: $q_{j}=$ metallic ion $\mathrm{j}$ adsorption capacity $\left(\mathrm{mmol} \cdot \mathrm{g}^{-1}\right)$; $C_{j}^{0}=$ metallic ion $\mathrm{j}$ initial concentration $\left(\mathrm{mmol}_{\mathrm{L}} \mathrm{L}^{-1}\right)$; $C_{f}=$ metallic ion final concentration after equilibrium has been reached $\left(\mathrm{mmol} . \mathrm{L}^{-1}\right) ; V=$ solution volume $(\mathrm{L})$; $m_{s}=$ adsorbent dry mass $(\mathrm{g})$.

\subsection{Equilibrium bioadsorption}

In order to obtain equilibrium bioadsorption data for metallic ions, the static method was used, where a series of solutions $(100 \mathrm{~mL})$ with different metallic ion concentrations were placed in contact with $0.2 \mathrm{~g}$ bioadsorbent, at a temperature of $25{ }^{\circ} \mathrm{C}$, under agitation at $250 \mathrm{rpm}$ and $\mathrm{pH}=4.5$, adjusted with nitric acid at $0.05 \mathrm{M}$. The Langmuir Isotherm model was used to adjust the equilibrium data. The adjustment was performed by non-linear regression using the software Origin 6.0.

\section{Results and Discussions}

\subsection{Calcium alginate beads obtained before and after the drying process}

Figure 1a presents the beads, in gel form, obtained from the jellification of sodium alginate (extracted from the alga) in calcium chloride, before the drying process.

Micrographs for the dry calcium alginate beads are presented in Figure 1b-d with 50-, 150- and 3000-fold magnification. It can be observed that the surface is very rugged and presents depressions, resulting from the shrinking that takes place during the drying process. The rugosity can increase the superficial area, easing the diffusion of metal ions in the particle. Lagoa \& Rodrigues ${ }^{12}$ observed a similar appearance for dry beads with $2 \%$ sodium alginate, although they were not as spherical as the ones presented in Figure 1. The diameter of moist beads, calculated by the SigmaScan Pro 4 software, was $3.14 \mathrm{~mm} \pm 0.18$, while the sphericity was $0.83 \pm 0.02$. The dry spheres presented diameter of $1.02 \mathrm{~mm} \pm 0.75$ and sphericity of $0.82 \pm 0.07$.

\subsection{Evaluation of functional groups presented in marine alga Sargassum filipendula and extracted alginate biopolymer}

Fourier Transform Infrared (FT-IR) analysis has been frequently used to detect how vibrational frequencies (bands) vary in marine algae ${ }^{13-17}$. This technique offers excellent information on the nature of the present bands, allowing the identification of different functionalities on the 


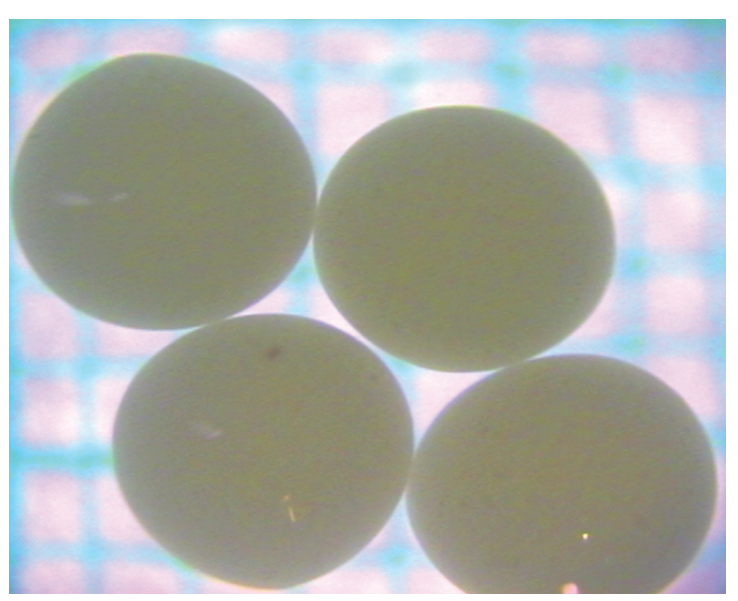

(a)

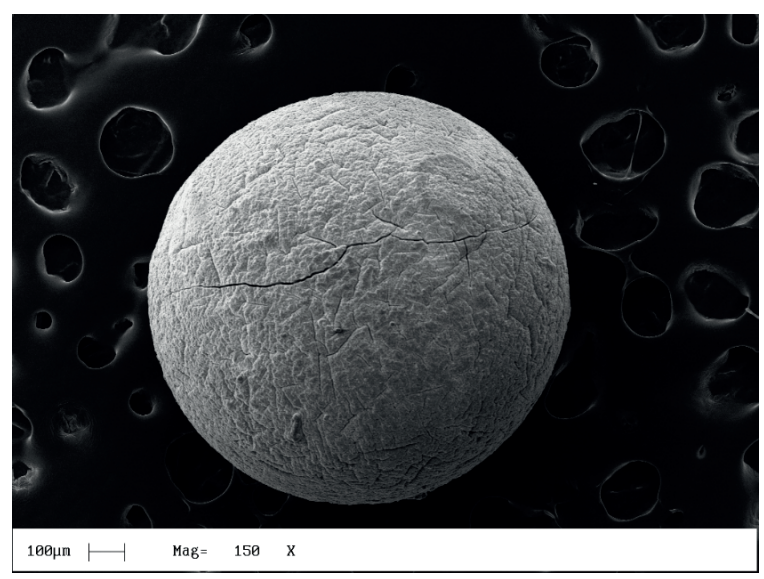

(c)

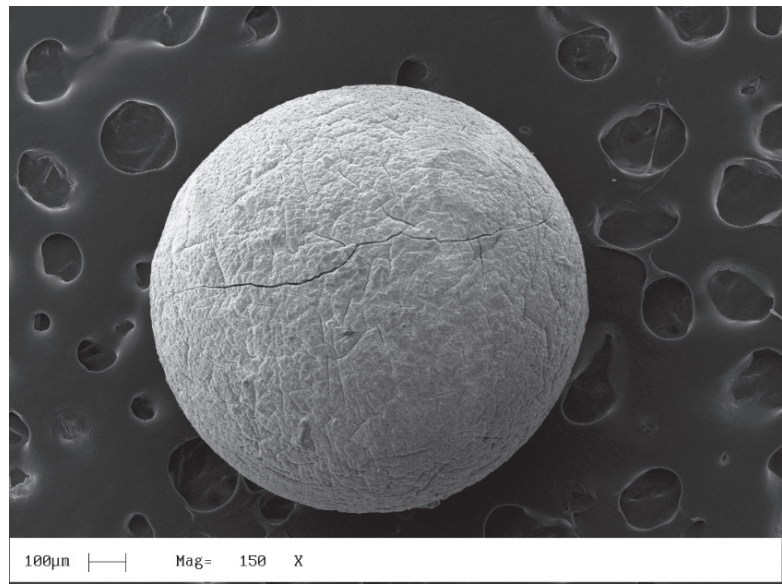

(b)

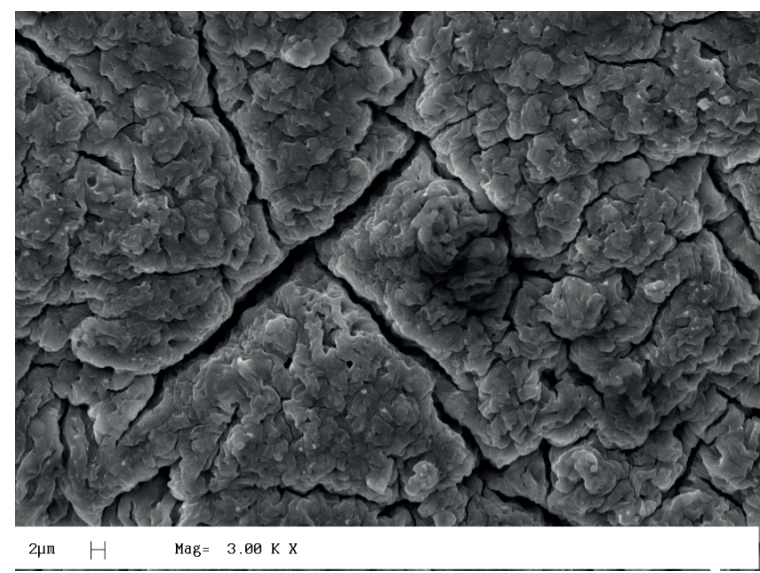

(d)

Figure 1. Micrographs from alginate beads, increases of a) moist bead b) 50, c) 150 and d) 3000 fold.

cellular surface. Band shifting provides an indication of the functional group interaction with metallic ions.

\subsection{Identification of functional groups present in Sargassum filipendula alga}

By analyzing the spectra obtained for the marine alga S. filipendula, the following bands and corresponding related functional groups were identified:

The 1414- and $1616-\mathrm{cm}^{-1}$ bands are attributed to carboxylic $(\mathrm{COOH})$ groups present in the alginate biopolymer ${ }^{18,16}$. The band at $1229 \mathrm{~cm}^{-1}$ is attributed to sulfate $\left(\mathrm{SO}_{3}\right)$ groups present in the fucoidan biopolymer ${ }^{16}$. The band at $1537 \mathrm{~cm}^{-1}$ is attributed to amino groups present in proteins ${ }^{19,15}$. The band at $1029 \mathrm{~cm}^{-1}$ is attributed to alcohol groups $^{1}$. Also, according to Mathlouthi and Koenig ${ }^{18}$, the band frequency between 3200 and $3500 \mathrm{~cm}^{-1}$ corresponds to amino $\left(-\mathrm{NH}_{2}\right)$ and alcohol $(-\mathrm{OH})$ groups.

\subsection{Identification of functional groups present in the alginate biopolymer extracted from the Sargassum filipendula alga}

By analyzing the spectra obtained for the alginate extracted from marine alga $S$. filipendula, the following bands and corresponding related functional groups were identified: 1418 - and $1620-\mathrm{cm}^{-1}$ bands present in mannuronic $(\mathrm{M})$ and guluronic $(\mathrm{G})$ acids in the alginate biopolymer ${ }^{18,16} ; 1320-, 1123$ - and $1086-\mathrm{cm}^{-1}$ bands correspond to $\mathrm{CC}, \mathrm{CO}$ and $\mathrm{CCH}$ groups ${ }^{14}$, present in acids forming the alginate biopolymer. 1026- and 3443- $\mathrm{cm}^{-1}$ bands are attributed to alcohol groups ${ }^{16}$. The bands identified for mannuronic and guluronic groups were at $815 \mathrm{~cm}^{-1}$ and $778 \mathrm{~cm}^{-1}$, respectively.

\subsection{Efficiency of the extraction process}

Initially, a comparison between the spectra obtained for marine alga $S$. filipendula and the alginate biopolymer extracted from this alga was performed. The alginate extraction yield from the marine alga S. filipendula was $17 \%$. According to Percival and McDowell ${ }^{20}$, the amount of alginate present in brown algae ranges from 10 to $40 \%$. It can be observed that the band attributed to the sulfate group in the fucoidan biopolymer and the bands corresponding to protein amino groups present in the marine alga disappear in the spectrum obtained for the extracted alginate, indicating efficiency in the extraction. For alginate extracted from the alga, the identified bands corresponded to carboxylic, alcohol groups, as well as mannuronic and guluronic acids forming the biopolymer. It can also be noticed, in the 
spectrum obtained for the extracted alginate, the appearance of $1320-, 1123$ - and $1086-\mathrm{cm}^{-1}$ bands corresponding to CC, $\mathrm{CO}$ and $\mathrm{CCH}$ groups present in mannuronic and guluronic acids forming the alginate biopolymer.

\subsection{Changes after the bioadsorption of different metallic ions by marine alga Sargassum filipendula}

Figure 2 presents the spectra obtained for the marine alga S. filipendula before and after the bioadsorption of different metallic ions. Table 1 presents the changes suffered by the bands after the bioadsorption of different metallic ions by marine alga $S$. filipendula.

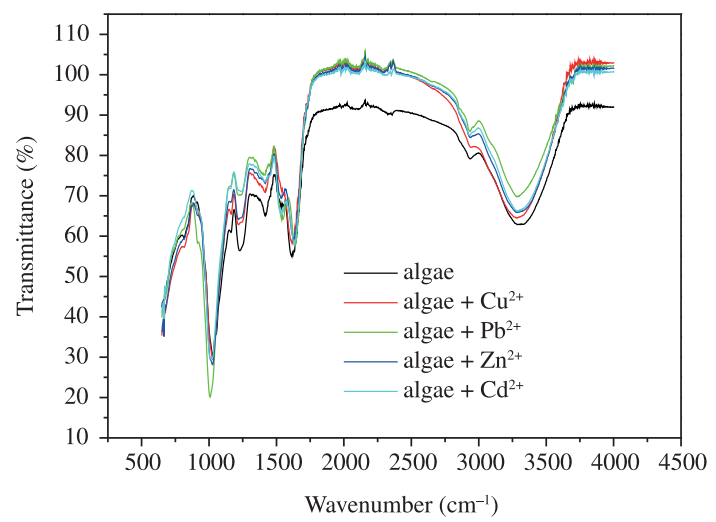

Figure 2. Fourier transform infrared (FT-IR) spectra of S. filipendula alga and saturated with $\mathrm{Cu}^{2+}, \mathrm{Pb}^{2+}, \mathrm{Zn}^{2+}$ and $\mathrm{Cd}^{2+}$.

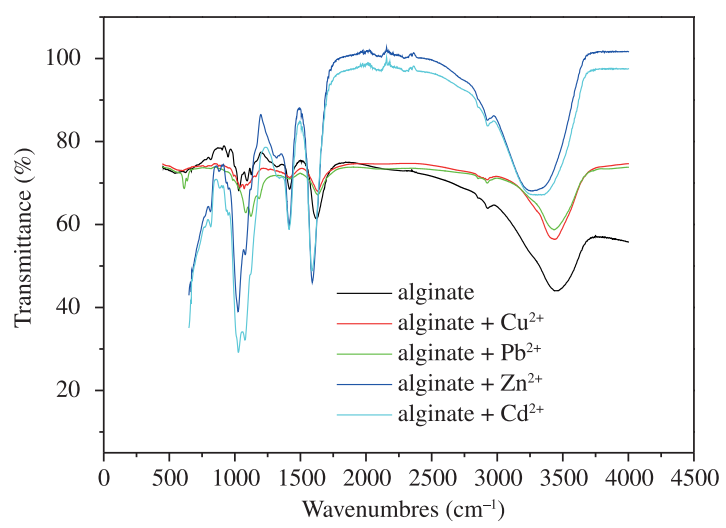

Figure 3. Fourier transform infrared (FT-IR) spectra of extracted alginate and saturated with $\mathrm{Cu}^{2+}, \mathrm{Pb}^{2+}, \mathrm{Zn}^{2+}$ and $\mathrm{Cd}^{2+}$.
Shifts in the 1416- and $1614-\mathrm{cm}^{-1}$ bands can be seen, which represent the carboxylic groups in the alginate biopolymer. According to Sheng et al. ${ }^{16}$, the $1640-\mathrm{cm}^{-1}$ band is due to COO-M carboxylic groups, where $\mathrm{M}$ can be $\mathrm{Na}^{+}$, $\mathrm{K}^{+}, \mathrm{Ca}^{+}$or $\mathrm{Mg}^{+}$, naturally present in brown marine algae. Since these species are competition elements, this result indicates that the ionic exchange process is taking place.

By analyzing the shift in $1537-\mathrm{cm}^{-1}$ band, its disappearance after the bioadsorption of $\mathrm{Cu}^{2+}$ and displacement to $1531 \mathrm{~cm}^{-1}$ after the bioadsorption of the remaining ions can be observed, indicating that the amino groups, present in proteins, are involved in the bioadsorption process of these ions.

The spectra corresponding to 1240 - and $1034-\mathrm{cm}^{-1}$ bands represent the $\mathrm{SO}_{3}$ groups in the fucoidan biopolymer and the alcohol group in the alginate biopolymer. It can be observed that these groups are participating in the bioadsorption process of all metallic ions, since the ions cause the shifting of this band. It is also noticed that the alcohol group suffered a more significant shift when $\mathrm{Pb}^{2+}$ ion was present in the solution.

The bands corresponding to mannuronic and guluronic acids, which form the alginate biopolymer, disappear after the ion bioadsorption process, indicating the strong participation of these groups in that process.

Kleinübing et al. ${ }^{13}$ studied the functional groups present in marine alga $S$. filipendula, before and after the bioadsorption of $\mathrm{Cu}^{2+}$ and $\mathrm{Ni}^{2+}$ metallic ions using FT-IR technique. The authors noticed that the carboxylic $(\mathrm{COOH})$ and alcohol groups present in the alginate biopolymer, the sulfate $\left(\mathrm{SO}_{3}\right)$ groups present in the fucoidan biopolymer and the amino groups present in the proteins participate in the bioadsorption process of metallic ions.

\subsection{Changes after the bioadsorption of different metallic ions by the alginate extracted from the alga}

Figure 3 presents the spectra obtained for the alginate extracted from the marine alga S. filipendula, before and after the bioadsorption of different metallic ions. Table 2 presents the shifts suffered by the bands after the bioadsorption of different metallic ions by the alginate biopolymer extracted from the alga.

Shifts can be observed in the $1618-\mathrm{cm}^{-1}$ band, which represents the carboxylic groups, COO-M, where $\mathrm{M}$ stands for calcium ions used in the jellification process for the formation of calcium alginate beads, indicating that the ionic exchange mechanism between the metallic ions and calcium ions is working.

For all ions, shifts in 1320-, 1123- and $1086-\mathrm{cm}^{-1}$ bands correspond to the $\mathrm{CC}, \mathrm{CO}$ and $\mathrm{CCH}$ groups, present in

Table 1. Shifting observed in the bands.

\begin{tabular}{ccccc}
\hline S. filipendula $\left(\mathbf{c m}^{-1}\right)$ & $\mathbf{P b}^{2+}\left(\mathbf{c m}^{-1}\right)$ & $\mathbf{C u}^{2+}\left(\mathbf{c m}^{-1}\right)$ & $\mathbf{C d}^{2+}\left(\mathbf{c m}^{-1}\right)$ & $\mathbf{Z n}^{2+}\left(\mathbf{c m}^{-1}\right)$ \\
\hline 1614 & 1632 & 1617 & 1632 & 1632 \\
1537 & 1531 & - & 1531 & 1531 \\
1416 & 1411 & 1411 & 1411 & 1418 \\
1229 & 1226 & 1232 & 1233 & 1226 \\
1029 & 1009 & 1027 & 1028 & 1028 \\
819 & - & - & - & - \\
\hline
\end{tabular}


acids forming the alginate biopolymer. The $1320-\mathrm{cm}^{-1}$ band disappeared in the presence of $\mathrm{Pb}^{2+}$ and $\mathrm{Cu}^{2+}$ ions, and was shifted to $\mathrm{Cd}^{2+}$, indicating the importance of the $\mathrm{CC}$ group in capturing these ions. The $1086-\mathrm{cm}^{-1}$ band presented a more significant shifting in the presence of $\mathrm{Pb}^{2+}$. The band at 1123 presented a significant shifting in the presence of $\mathrm{Pb}^{2+}$ and $\mathrm{Cu}^{2+}$ ions, and disappeared in the presence of $\mathrm{Cd}^{2+}$ and $\mathrm{Zn}^{2+}$ ions, indicating the importance of the $\mathrm{CO}$ group in removing metallic ions.

The band at $1026 \mathrm{~cm}^{-1}$ attributed to alcohol groups was shifted in the presence of ions, emphasizing the $\mathrm{Pb}^{2+}$ ion with very significant results. The bands corresponding to the mannuronic and guluronic groups forming the alginate biopolymer were shifted after the ion bioadsorption process, showing the effective participation of these acids in the bioadsorption process.

\subsection{Comparison between bioadsorption kinetics of metallic ions by marine alga S. filipendula and alginate extracted from the alga}

Figure 4 presents the bioadsorption kinetic curves of different metallic ions by the marine alga S. filipendula and by the alginate biopolymer extracted from the alga. It can be observed that for the marine alga S. filipendula, the kinetic

Table 2. Shifting observed in the bands.

\begin{tabular}{|c|c|c|c|c|}
\hline Alginate $\left(\mathrm{cm}^{-1}\right)$ & $\mathrm{Pb}^{2+}\left(\mathbf{c m}^{-1}\right)$ & $\mathrm{Cu}^{2+}\left(\mathrm{cm}^{-1}\right)$ & $\mathrm{Cd}^{2+}\left(\mathrm{cm}^{-1}\right)$ & $\mathrm{Zn}^{2+}\left(\mathbf{c m}^{-1}\right)$ \\
\hline 1618 & 1636 & 1628 & 1585 & 1589 \\
\hline 1418 & 1418 & 1418 & 1418 & 1411 \\
\hline 1320 & - & - & 1341 & 1319 \\
\hline 1123 & 1184 & 1162 & - & - \\
\hline 1086 & 1123 & 1072 & 1077 & 1078 \\
\hline 1026 & 1078 & 1041 & 1028 & 1027 \\
\hline 815 & 822 & 883 & 813 & 807 \\
\hline 778 & - & 770 & - & - \\
\hline
\end{tabular}

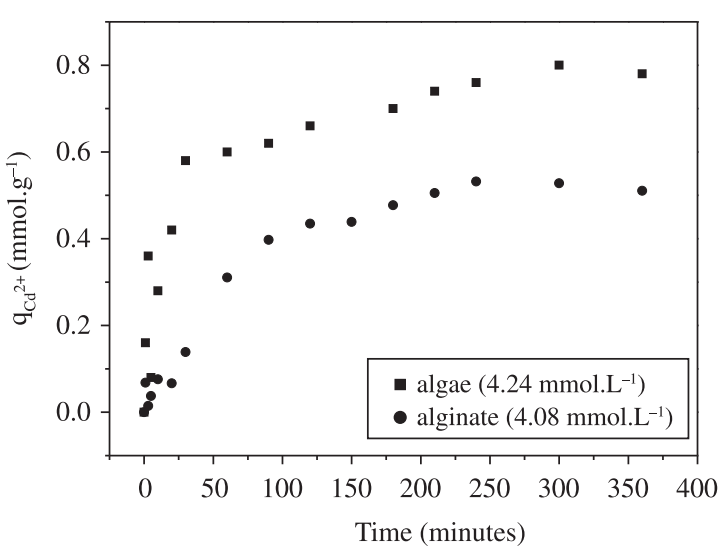

(a)

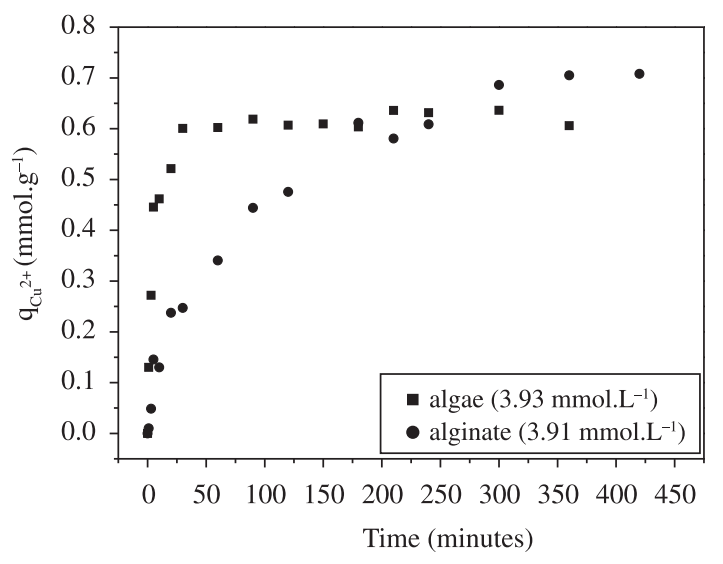

(c)

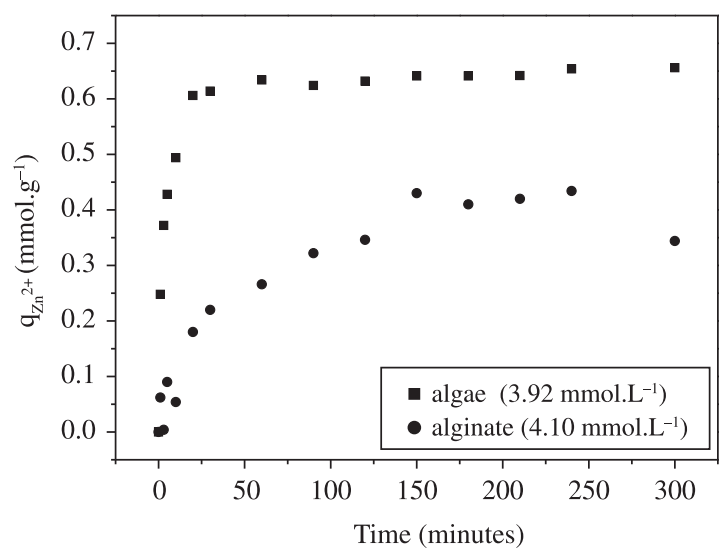

(b)

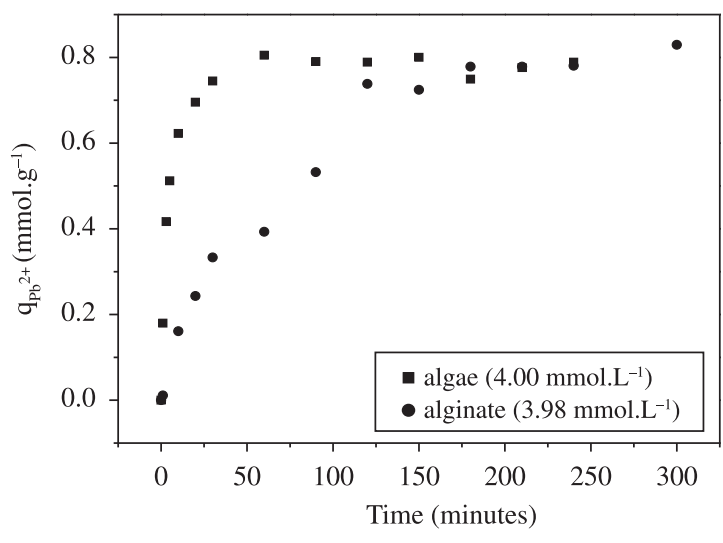

(d)

Figure 4. Bioadsorption kinetics obtained for marine alga S. filipendula and calcium alginate beads extracted from this alga for ions: a) $\mathrm{Cd}^{2+}$, b) $\mathrm{Zn}^{2+}$, c) $\mathrm{Cu}^{2+}$ and d) $\mathrm{Pb}^{2+}$. 
is very fast at the beginning, tending towards an equilibrium state before 100 minutes, except for the $\mathrm{Cd}^{2+}$ ion, which took approximately 250 minutes to reach equilibrium. Different behaviors in the bioadsorption kinetic curves of metallic ions by alginate biopolymer extracted from the alga were observed, with changes in the shape of curves and increase in the time needed to reach equilibrium. The curve becomes longer, indicating that resistance to the transfer of mass in the calcium alginate particles is taking place.

The alginate is extracted from the alga in the form of sodium alginate, and in order to be used as bioadsorbent, it is jellified in the form of calcium alginate. Since the ionic exchange is the main mechanism responsible for removing metallic ions in the alginate biopolymer, the greater resistance to mass transfer observed for the alginate in comparison to the alga can be related to the exclusive presence of calcium ion in the alginate, whereas in the alga, different ions such as $\mathrm{Mg}^{2+}, \mathrm{Na}^{2+}, \mathrm{Al}^{2+}, \mathrm{Si}^{2+}, \mathrm{Ca}^{2+}$ are naturally presented ${ }^{21}$. These ions present in the biomass are more easily exchanged when compared to the calcium ion in the calcium alginate. Consequently, a greater resistance to mass transfer and an increase in the time needed to reach adsorption equilibrium could be noticed for the alginate biopolymer.

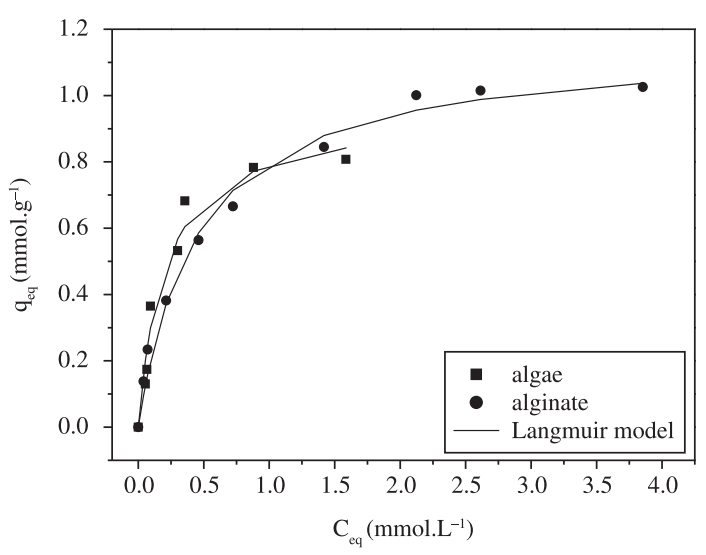

(a)

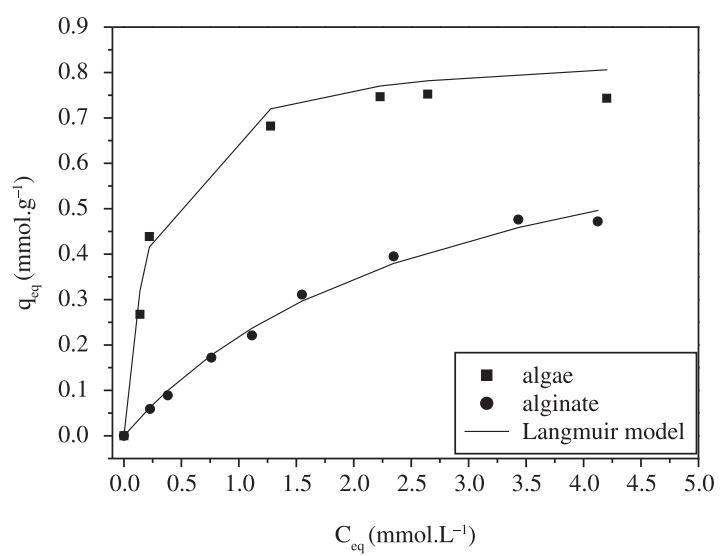

(c)

\subsection{Comparative study of the equilibrium of different metallic ions by the marine alga Sargassum filipendula and by the extracted alginate}

Figure 5 shows the bioadsorption isotherms for $\mathrm{Pb}^{2+}$, $\mathrm{Cu}^{2+}, \mathrm{Cd}^{2+}$ and $\mathrm{Zn}^{2+}$ in marine alga $S$. filipendula and in calcium alginate beads, with adjustment by Langmuir model. Table 3 presents the parameters obtained from these adjustments.

The following affinity order was observed for the marine alga $S$. filipendula and for the alginate biopolymer extracted from the alga by the metallic ions: $\mathrm{Pb}^{2+}>\mathrm{Cu}^{2+}>$ $\mathrm{Zn}^{2+}>\mathrm{Cd}^{2+}$. It is important to emphasize the role of this biopolymer in the removal of $\mathrm{Pb}^{2+}$ and $\mathrm{Cu}^{2+}$ ions. For these ions, when the alginate is isolated, it acts as a bioadsorbent, and adsorption capacities higher than those found for marine alga $S$. filipendula were found, indicating that this is the main group responsible for the removal of metallic ions.

Haug $^{22}$ studied the release of ions present in the alginic acid extracted from the Laminaria digitata alga with the presence of different heavy metals in solution. In the paper, the authors could observe the exchange between ions existing in the alginate and the heavy metals present in the solution and, also, that the amount of exchanged protons

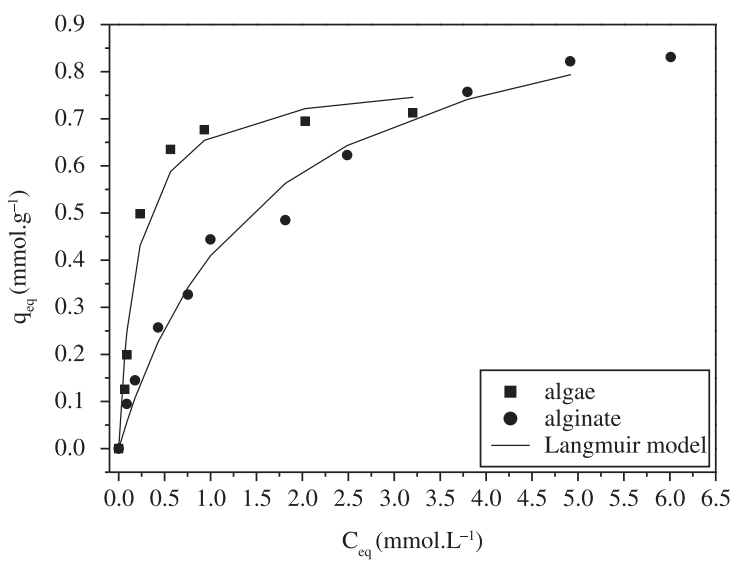

(b)

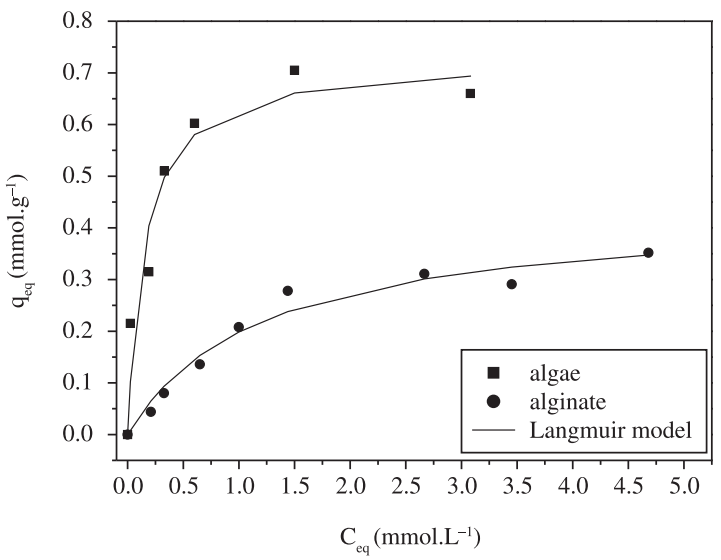

(d)

Figure 5. Langmuir model adjusted to bioadsorption isotherms for $\mathrm{Pb}^{2+}(\mathrm{a}), \mathrm{Cu}^{2+}(\mathrm{b}), \mathrm{Zn}^{2+}(\mathrm{c})$ and $\mathrm{Cd}^{2+}(\mathrm{d})$ by alga and alginate bioadsorbents 
Table 3. Langmuir parameters estimated in the removal of ions in marine alga S. filipendula and alginate extracted from the alga.

\begin{tabular}{|c|c|c|c|c|c|c|}
\hline \multirow{3}{*}{ Metal } & \multicolumn{6}{|c|}{ Langmuir parameters } \\
\hline & \multicolumn{3}{|c|}{ S. filipendula } & \multicolumn{3}{|c|}{ Extracted alginate } \\
\hline & $q_{m}\left({\left.\mathrm{mmol} . \mathrm{g}^{-1}\right)}^{-1}\right.$ & $b_{j}\left(\mathrm{~L} \cdot \mathrm{mmol}^{-1}\right)$ & $R^{2}$ & $q_{m}\left(\mathrm{mmol.g}^{-1}\right)$ & $b_{j}\left(\right.$ L.mmol $\left.^{-1}\right)$ & $R^{2}$ \\
\hline $\mathrm{Pb}^{2+}$ & $0.95 \pm 0.07$ & $4.94 \pm 1.11$ & 0.97 & $1.16 \pm 0.042$ & $2.22 \pm 0.294$ & 0.99 \\
\hline $\mathrm{Cu}^{2+}$ & $0.81 \pm 0.042$ & $4.92 \pm 1.02$ & 0.97 & $1.04 \pm 0.075$ & $0.65 \pm 0.116$ & 0.98 \\
\hline $\mathrm{Zn}^{2+}$ & $0.80 \pm 0.020$ & $4.45 \pm 0.56$ & 0.99 & $0.71 \pm 0.037$ & $0.44 \pm 0.061$ & 0.99 \\
\hline $\mathrm{Cd}^{2+}$ & $0.71 \pm 0.062$ & $7.02 \pm 2.66$ & 0.94 & $0.44 \pm 0.037$ & $0.83 \pm 0.190$ & 0.97 \\
\hline
\end{tabular}

varied according to the heavy metal in the following order: $\mathrm{Pb}^{2+}>\mathrm{Cu}^{2+}>\mathrm{Cd}^{2+}>\mathrm{Ba}^{2+}>\mathrm{Sr}^{2+}>\mathrm{Ca}^{2+}>\mathrm{Co}^{2+}>\mathrm{Ni}^{2+}>$ $\mathrm{Mn}^{2+}>\mathrm{Mg}^{2+}$.

However, for $\mathrm{Zn}^{2+}$ and $\mathrm{Cd}^{2+}$ ions, the opposite was observed. Greater bioadsorption capacities were observed for the marine alga in comparison to the alginate biopolymer, indicating that the other functional groups present in the alga, such as sulfate and amino, are important in the bioadsorption of these ions.

Moreover, although the link between biomass and metallic ions can be seen as an ionic exchange process between $\mathrm{H}^{+}$ions and metallic ions present in acid functional groups, the high degree of selectivity presented by biomass from certain ions suggest that some of them are directly coordinated with the functional groups via the formation of internal sphere complexes. This type of adsorption is particularly important for $\mathrm{Cu}^{2+}$ and $\mathrm{Pb}^{2+}$ ions.

The greater importance of covalent binding for $\mathrm{Cu}$ compared to $\mathrm{Ni}$ is due to the fact that while electrostatic attraction is equally strong for both metals, covalent binding constants are higher for $\mathrm{Cu}$ than for $\mathrm{Ni}^{23}$. The higher electronegativity to $\mathrm{Cu}$ leads to more equal (covalent) sharing of electrons with a ligand atom such as oxygen as it occurs in carboxyl groups ${ }^{24}$. Correspondingly, covalent binding was more important for $\mathrm{Cu}$ than for $\mathrm{Ni}$, which was bound predominantly by electrostatic attraction.

\section{References}

1. Volesky B. Detoxification of metal-bearing effluents: biosorption for the next century. Hydrometallurgy. 2001; 59:203-216. http:// dx.doi.org/10.1016/S0304-386X(00)00160-2

2. Kratochvil D and Volesky B. Advances in the Biosorption of Heavy Metals. Trends Biotechnology. 1998; 16:291-300. http:// dx.doi.org/10.1016/S0167-7799(98)01218-9

3. Haug A. The affinity of some divalent metals to different types of alginates. Acta Chemica Scandinavica. 1961; 15:1794-1795. http://dx.doi.org/10.3891/acta.chem.scand.15-1794

4. Haug A and Smidsrod O. Selectivity of some anionic polymers for divalent metal ions. Acta Chemica Scandinavica. 1970; 24:843-54. http://dx.doi.org/10.3891/acta.chem.scand.24-0843

5. Papageorgiou SK, Katsaros FK, Kouvelos EP, Nolan JW, Le Deit H and Kanellopoulos NK. Heavy metal sorption by calcium alginate beads from Laminaria digitata. Journal of Hazardous Materials. 2006; 137(3):1765-1772. PMid:16797834. http:// dx.doi.org/10.1016/j.jhazmat.2006.05.017

6. Kleinübing SJ, Guibal E, Da Silva EA and Da Silva MGC. Copper and nickel competitive biosorption simulation from single and binary systems by Sargassum filipendula.

\section{Conclusions}

This paper focused on the bioadsorption of $\mathrm{Pb}^{2+}, \mathrm{Cu}^{2+}$, $\mathrm{Cd}^{2+}$ and $\mathrm{Zn}^{2+}$ ions by the marine alga Sargassum filipendula and by the alginate biopolymer extracted from this alga. With the results obtained, it was possible to conclude that the marine alga $S$. filipendula adsorbs the metallic ions in a different manner. The same ion affinity order was found for both bioadsorbents $\left(\mathrm{Pb}^{2+}>\mathrm{Cu}^{2+}>\mathrm{Zn}^{2+}>\mathrm{Cd}^{2+}\right)$. However, $\mathrm{Pb}^{2+}$ and $\mathrm{Cu}^{2+}$ ions presented high affinity both by the marine alga $S$. filipendula and by the alginate extracted from the alga. The $\mathrm{Zn}^{2+}$ and $\mathrm{Cd}^{2+}$ ions presented reduced removal capacities in the extracted alginate when compared to the alga, indicating that functional groups such as sulfates and amino present in the alga are important in the removal of these ions. By analyzing the FT-IR, it can be concluded that the extraction process for the biopolymer was efficient and that the functional groups present in the alga and in the alginate extracted from the alga are participating in the bioadsorption process of all metallic ions studied herein.

\section{Acknowledgements}

The authors would like to acknowledge CAPES/PNPD and FAPESP for the financial support and CEBIMar (USP) for collection and identification of the algal material.

Chemical Engineering Journal. 2012; 184:16-22. http://dx.doi. org/10.1016/j.cej.2011.11.023

7. Vieira MGA, Oisiovici RM, Gimenes ML and Da Silva MGC. Biosorption of Chromium (VI) using a Sargassum sp PackedBed Column. Bioresource Technology. 2008; 99(8): 3094-3099. PMid:17689245. http://dx.doi.org/10.1016/j.biortech.2007.05.071

8. Fagundes-Klen MR, Ferri P, Martins TD, Tavares CRG and Silva EA. Equilibrium study of the binary mixture of cadmium-zinc ions biosorption by the Sargassum filipendula species using adsorption isotherms models and neural network. Biochemical Engineering Journal. 2007; 34:136-146. http:// dx.doi.org/10.1016/j.bej.2006.11.023

9. Da Silva EA, Cossich ES, Tavares, CRG, Cardozo Filho L and Guirardello R. Modeling of Copper(II) Biosorption by Marine Alga Sargassum sp. in Fixed-Bed Column. Process Biochemistry. 2002; 38:791-799. http://dx.doi.org/10.1016/ S0032-9592(02)00231-5

10. Glicksman M. Red seaweed extracts. In: Glicksman M, editor. Food Hydrocolloids. Boca Raton: CRC Press, Inc.; 1983.

11. McHugh DJ. Production, properties and uses of Alginates. FAO Fisheries Technical Papers. 1987; 58-115. 
12. Lagoa R and Rodrigues JR. Kinetic analysis of metal uptake by dry and gel alginate particles. Biochemical Engineering Journal. 2009; 46(3):320-326. http://dx.doi.org/10.1016/j. bej.2009.06.007

13. Kleinübing SJ, Vieira RS, Beppu M, Guibal E and Da Silva MGC. Characterization and Evaluation of Copper and Nickel Biosorption on Acidic Algae Sargassum Filipendula. Materials Research. 2010; 13:1-10. http://dx.doi.org/10.1590/S151614392010000400018

14. Fuks L, Filipiuk D and Majdan M. Transition metal complexes with alginate biosorbent. Journal of Molecular Structure. 2006; 792-793:104-109. http://dx.doi.org/10.1016/j. molstruc.2005.12.053

15. Chen JP and Yang L. Study of a heavy metal biosorption onto raw and chemically modified Sargassum sp. via spectroscopic and modeling analysis. Langmuir. 2006; 22:8906-8914. PMid:17014134. http://dx.doi.org/10.1021/la060770+

16. Sheng PX, Ting Y-P, Chen JP and Hong L. Sorption of lead, copper, cadmium, zinc, and nickel by marine algal biomass: characterization of biosorptive capacity and investigation of mechanism. Journal Colloid and Interface Science. 2004; 275:131-141. PMid:15158390. http://dx.doi. org/10.1016/j.jcis.2004.01.036

17. Figueira MM, Volesky B and Matheus HJ. Instrumental analysis study of iron species biosorption by Sargassum biomass. Environmental Science and Technology. 1999; 33:1840-1846. http://dx.doi.org/10.1021/es981111p
18. Mathlouthi M and Koenig JL. Vibrational Spectra of Carbohydrates. Advances in Carbohydrate Chemistry and Biochemistry. 1986; 44:7-66. http://dx.doi.org/10.1016/S00652318(08)60077-3

19. Fourest E and Volesky B. Contribution of sulphonate groups and alginate to heavy metal biosorption by the dry biomass of Sargassum fluitans. Environmental Science and Technology. 1996; 30(1):277-282. http://dx.doi.org/10.1021/ es950315s

20. Percival EGV and McDowell RH. Chemistry and Enzymology of Marine Algal Polysaccharides. London: Academic Press; 1967. p. 219.

21. Kleinübing SJ, Da Silva EA, Da Silva MGC and Guibal E. Equilibrium of $\mathrm{Cu}(\mathrm{II})$ and $\mathrm{Ni}(\mathrm{II})$ biosorption by marine alga Sargassum filipendula in a dynamic system: Competitiveness and selectivity. Bioresource Technology. 2011; 102(7):4610-4617. PMid:21295972. http://dx.doi.org/10.1016/j. biortech.2010.12.049

22. Haug A, Larsen B and Smidsrod O. Uronic acid sequence in alginate from different sources. Carbohydrate Research. 1974; 32:217-25. http://dx.doi.org/10.1016/S00086215(00)82100-X

23. Schiewer $\mathrm{S}$ and Wong MH. Ionic strength effects in biosorption of metals by marine algae. Chemosphere. 2000; 41:271-282. http://dx.doi.org/10.1016/S0045-6535(99)00421-X

24. Stumm W and Morgan JJ. Aquatic chemistry - chemical equilibria and rates in natural waters. New York: John Wiley \& Sons; 1996. 1022 p. 